\title{
PRELIMINARY NOTES ON THE GLAGIOLOGY OF KILIMANJARO
}

\author{
By D. W. Humphries \\ (Department of Geology, University of Sheffield)
}

\begin{abstract}
Glaciological studies during the Sheffield University Expeditions to Kilimanjaro in 1953 and 1957 included a survey of the glaciers and a close examination of the Penck Glacier and the stagnant remnants of the ice cap on the summit. The Penck Glacier has done little downcutting although it rests on friable rock. The glaciers and summit remnants are rapidly retreating, the Penck Glacier having retreated $3 \mathrm{~m}$. in 3 months in 1957 , and nearly $300 \mathrm{~m}$. since 1912 . The main accumulation zone appears to be at about 4,500-5,000 m. with a local "low level" firn line and an upper firn line above the top of the mountain. Maps of the glaciers, their recent fluctuations and moraines are being prepared. The glaciological and meteorological observations in 1957 form part of the I.G.Y. programme for East Africa.
\end{abstract}

RÉsumé. Les études glaciologiques faites par les expéditions de l'université de Sheffield au Kilimanjaro en 1953 et 1957 comprennent une étude des glaciers et un examen approfondi du Glacier de Penck et des vestiges stagnants de la chape de glace au sommet. Le Glacier de Penck a donné lieu à peu d'érosion latérale en dépit du fait qu'il repose sur une roche friable. Les glaciers et les vestiges au sommet sont en retrait rapide, le Glacier de Penck a subi un retrait de $3 \mathrm{~m}$ en 3 mois en 1957 et de près de $300 \mathrm{~m}$ depuis 1912. La zone d'accumulation principale semble se situer à $4500-5000 \mathrm{~m}$ environ, avec un névé local à "bas niveau" et un névé supérieur au dessus du sommet des montagnes. Des cartes des glaciers ainsi que de leurs fluctuations récentes et des moraines sont en voie de préparation. Les observations glaciologiques et météorologiques de 1957 font partie du programme de l'A.I.G. pour l'Afrique Orientale.

Zusammenfassung. Glaziologische Studien während der Expeditionen der Universität Sheffield zum Kilimanjaro in den Jahren 1953 und 1957 enthalten eine Übersicht der Gletscher und eine eingehende Untersuchung des Penck Glacier und der stagnierenden Ưberbleibsel der Eiskalotte am Gipfel. Der Penck Glacier hat eine gewisse Erosion verrichtet, obwohl er auf bröckligen Felsen liegt. Die Gletscher und die Gipfel-Úberreste gehen rapide zurück. So ist der Penck Glacier im Jahre 1957 in 3 Monaten $3 \mathrm{~m}$ zurückgegangen und seit 1912 beinahe $300 \mathrm{~m}$. Die Hauptakkumulationszone scheint ungefähr $4500-5000 \mathrm{~m}$ zu sein mit einer lokalen Firnlinie "niedrigen Niveaus" und einer oberen Firnlinie über dem Gipfel des Berges. Karten der Gletscher mit ihren Schwankungen und Moränen befinden sich in Vorbereitung. Die glaziologischen und meteorologischen Beobachtungen des Jahres 1957 bilden einen Teil des I.G.Y. Programmes für Ostafrika.

During the summer of 1957 the Geological Department of the University of Sheffield sent six staff-members to the Kilimanjaro Massif, Tanganyika Territory, to continue studies commenced in 1953 and to obtain glaciological and meteorological data for the I.G.Y.

\section{INTRODUCTION}

Kilimanjaro, Africa's highest mountain, stands on the southern side of the KenyaTanganyika border some 200 miles south of the equator and at about the same distance from the Indian Ocean in latitude $3^{\circ} 05^{\prime} \mathrm{S}$. and longitude $37^{\circ} 2 \mathrm{I}^{\prime} \mathrm{E}$. This volcanic massif, about I 30 miles (209 km.) in circumference at the base, rises from arid plains at about 4, ooo $\mathrm{ft}$. $(\mathrm{r}, 220 \mathrm{~m}$.) through a cultivated zone, dense rain forest, moorland and alpine desert to culminate in three great peaks, Shira, Kibo, and Mawenzi. Of these Kibo ( $19,340 \mathrm{ft} ., 5,895 \mathrm{~m}$.), the central cone, is the highest and the only peak to retain glaciers. Mawenzi (r6,896 ft., $5, \mathrm{I} 5 \mathrm{O}$.) to the east has semi-permanent snow patches, while to the west, the Shira Ridge rising to $\mathrm{I}_{3}, \mathrm{I} 4 \mathrm{O} \mathrm{ft}$. (4, O IO m.) bears only traces of past glacierizations. There is ample evidence of considerable glacierization in the past with glaciers extending down to at least $\mathrm{I}$,, $00 \mathrm{ft}$. $(3,350 \mathrm{~m}$.) although the lowest snout at the present time is at about $\mathrm{I} 5,000 \mathrm{ft}$. $(4,58 \mathrm{om}$.).

\section{The Glaciers of Kibo}

Kibo is a "puy"-shaped cone rising from Saddle-level (about r 4 ,ooo ft., 4,270 m.) and is more than 15 miles $(24 \mathrm{~km}$.) in circumference. The summit region has subsided to form a spectacular caldera $\mathrm{I} \frac{1}{2}$ miles $(2.4 \mathrm{~km}$.) in diameter with inner walls $600 \mathrm{ft}$. $(\mathrm{I} 83 \mathrm{~m}$.) deep on 
the south side. Within this lies the Inner Cone, rising to $19,000 \mathrm{ft}$. and enclosing a crater 900 yards $(823 \mathrm{~m}$.) across. Inside the Inner Crater is a third cone, with a central crater. The Caldera wall is breached on the south-west side by the Great West Notch and the Kibo Barranco.

The glaciers of Kibo are the ragged fringe of an ice cap which, it is believed, covered the summit of the mountain. The centre of this ice cap has largely disintegrated and only small stagnant masses of ice remain in the outer crater (Fig. I, p. 479). The precise age of the ice cap is unknown, nor is it certain when disintegration commenced. When Meyer reached the summit in $1889^{\mathrm{I}}$ the break-up was far advanced. The most extensive glaciers are on the south-western flanks, the longest being the Penck Glacier. Some ten or eleven more glaciers are recognized on the south-western and southern flanks, but all are quite small. On the northern slopes, the lowest ice is at $\mathrm{r} 8,500 \mathrm{ft}$. $(5,640 \mathrm{~m}$.). A map of the glaciers and summit remnants is being made.

\section{The Penck Glacier (Fig. 2)}

This, the longest glacier, extends from the crater rim at about $19,000 \mathrm{ft}$. ( $5,800 \mathrm{~m}$.) to about $15,000 \mathrm{ft}$. $\left(4,580 \mathrm{~m}\right.$.) in a distance of $1 \frac{1}{2}$ miles $(2.4 \mathrm{~km}$.). Its width is of the order of $650 \mathrm{ft}$. (200 m.). The thickness of the ice at the margins of the glacier is between 30 and 40 feet $(9-12 \mathrm{~m}$.). The glacier terminates in a low wall of ice varying between $\mathrm{I}$ and ro feet $(0 \cdot 3-3 \mathrm{~m}$.$) in height.$

The glacier is remarkable for the small amount of work it has done on friable rock. Although there are quite large moraines below the snout, the glacier rests on the flank of Kibo "like a ribbon of toothpaste" and does not occupy a valley. Further work is in progress on this unusual glacier and the history of its moraines.

A photogrammetric survey has been made of the south-western flank of Kibo covering the Penck, Little Penck, Uhlig and Barranco Glaciers. The cairns used for this survey would enable a further survey to be made in due course. Photographs taken at stations used in both 1953 and r957 will enable an estimate to be made of the changes in the glaciers in that four-year period.

Cairns set up close to the snout of the Penck Glacier were destroyed because the ground moraine proved to be very unstable, probably due to contained ice. As a result of this no precise estimate of the amount of recession in the period July-September 1957 can be made, but it appears to be of the order of io ft. A photograph by Oehler (in Klute 1920) ${ }^{2}$ indicates that the glacier has retreated about 300 yards $(275 \mathrm{~m}$.) since 1912.

When the glacier was first visited in July 1957, the surface was bare, dry ice. A boring, about 200 yards $(60 \mathrm{~m}$.) from the snout, made to $\mathrm{I} 5 \mathrm{ft}$. $(4.5 \mathrm{~m}$.) showed uniform ice free from dirt bands. The temperature at the surface and at the bottom of the hole was $0^{\circ} \mathrm{C}$. Very shortly after this first visit, melting of the glacier surface began and continued throughout July, August and early September. Towards the end of September surface melting diminished as a result of a fall in air temperature and the accumulation of some 5 in. (1 $3 \mathrm{~cm}$.) of snow. How much of this snow became incorporated in the glacier is unknown, since the Expedition had to leave the mountain before any significant change had occurred. The total ablation in the snout area during the three months amounted to 14 in. $(35 \mathrm{~cm}$.) of ice, measured on a pole set up in the ice.

The left flank of the glacier near the snout showed pronounced steeply-inclined thrust planes, the traces of which could be clearly seen in the surface of the glacier. By the end of August the glacier surface had changed from being reasonably smooth to hummocky-the hummocks being one metre or more high. It would seem that differential movement along these thrust planes may have been of the same order of magnitude, but the fresh snow made further investigation impossible. 
No crevasses occur in the lower part of the glacier, but in the middle region there is a series of tension cracks, suggesting that some movement is still occurring. Near the snout no forward movement, other than that along the thrust planes, could be detected.

Lateral moraines some $200 \mathrm{ft}$. $(60 \mathrm{~m}$.) high flank the lower part of the Penck Glacier, while a series of concentric terminal moraines enclose the snout (Fig. 2).

\section{Kiвo Summit}

As mentioned earlier, Kibo is characterized by three well-defined, almost concentric craters. From the ridge of the outer crater wall the tops of the glaciers of the south side of the mountain are easily accessible. These glaciers commence generally in a vertical wall of ice reaching a maximum of $40 \mathrm{ft}$. ( $12 \mathrm{~m}$.) in the Heim Glacier. The ice is banded and in several instances there appears to have been marked erosion of the ice surface before further accumulations of snow. Dirt bands are rare. The tops of the Penck Glacier and the Northern Glacier smother the outer crater wall, which is probably much reduced in height. Nevertheless they also commence with a vertical wall of ice $100-150 \mathrm{ft}$. (30-45 m.) high which faces the centre of the crater. The upper walls of these glaciers are retreating rapidly down the flanks of the mountain. A gash in the Ratzel Glacier noted in 1953, had by 1957 increased in width by some 30 yards $(28 \mathrm{~m}$.). Many of the stagnant ice masses in this gash, which extends from the crater rim $(5,700 \mathrm{~m}$.) to the snout $(5,400 \mathrm{~m}$.), had disappeared in four years.

Within the outer crater there are a number of stagnant ice masses (Fig. I) which are the last remnants of the summit ice cap. Several small masses noted in 1953 have disappeared and others have diminished considerably. The high altitude of the sun, together with reflection from the moraine-covered surface of the outer crater floor, result in very striking fluting in the ice masses and a marked orientation of penitentes in an east to west direction. The cause of the massive steplike features in the Northern Glacier has not been satisfactorily explained.

\section{Accumulation and Ablation}

No measurements of annual accumulation and ablation have yet been made on Kibo, and although some records of precipitation on the mountain have been made available by the East African Meteorological Department, the figures for the upper part of Kibo are not considered to be reliable. Nevertheless some comments can be made. It is possible that there are two ablation periods corresponding to the two dry seasons of the plains of East Africa (i.e. a longer period from July to September and a brief period in January and February). It is confirmed that ablation commences in mid-July and probably ends in early October, but there is no evidence available as to the amount, if any, of the ablation in January and February. The rainfall records indicate that in some years there may be heavy precipitation in this period. It is probably reasonable, therefore, to presume that the total ablation at the snout of the Penck Glacier in 1957 did not greatly exceed $35 \mathrm{~cm}$., and therefore one may assume that the annual accumulation must be of the same order.

The main wet season is from March to June and this probably coincides with the main period of accumulation. The amount of precipitation, however, appears to diminish with increasing altitude on Kibo. This suggests that the main accumulation zone of, for example, the Penck Glacier is in the lower part and that a local "low-level" firn line exists. The presence of melting ice and pools of melt water at the summit during the day points to an upper firn line above the top of the mountain.

Further observations, particularly in the wet season, are essential to a fuller understanding of the regime of these unique equatorial glaciers.

\section{ACKNOWLedgements}

These observations were made in the Long Vacations of 1953 and 1957 while the writer was a member of the University of Sheffield Kilimanjaro Expeditions under the leadership 
of Mr. W. H. Wilcockson, M.A., F.G.S. The Expeditions were made possible by generous financial and other assistance from the British National Committee of the I.G.Y. (1957), the Colonial Development and Welfare Fund (1953), the Tanganyika Geological Survey, the Royal Society, the University of Sheffield and others, to all of whom the party is most grateful. The writer is particularly indebted to Professor Gordon Manley for much advice and encouragement.

\section{Note}

The writer would be most grateful for the loan of photographs of any part of Kibo, taken from the ground or from the air, to aid in the compilation (now in progress) of a map of recent glacier fluctuations. It is desirable that the approximate date of the photograph be known.

MS. received I6 May 1959

\section{REFERENGES}

1. Meyer, H. Die Besteigung des Kilimandjaro. Petermanns Geographische Mitteilungen, Bd. 36, 189o, p. 15-22.

2. Klute, F. Die Ergebnisse der Forschungen am Kilimandscharo, I9I2. Berlin, 1920. 


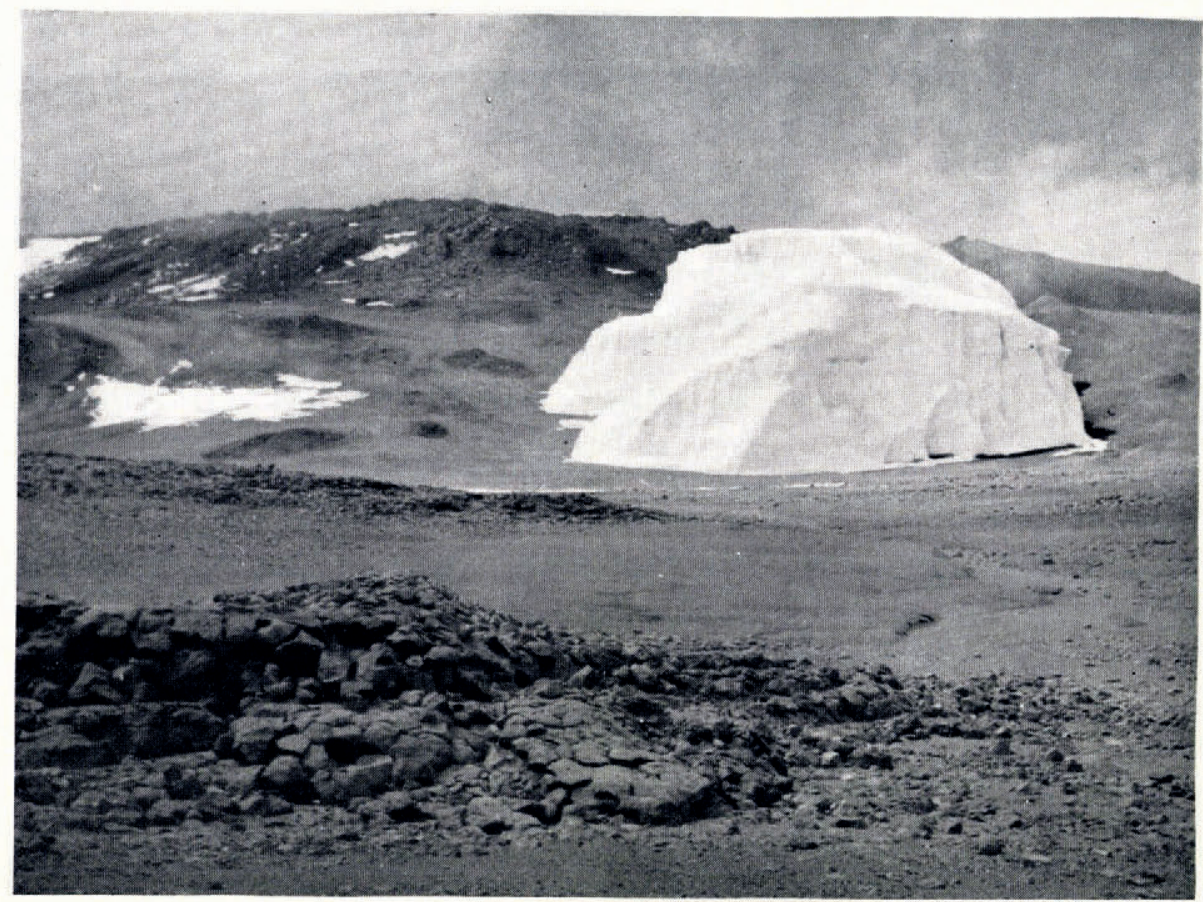

Fig. I. The Ice-dome, a stagnant remnant of ice (about $25 \mathrm{~m}$. high) in the Outer Crater of Kibo. Kilimanjaro. The Inner Cone rises just behind

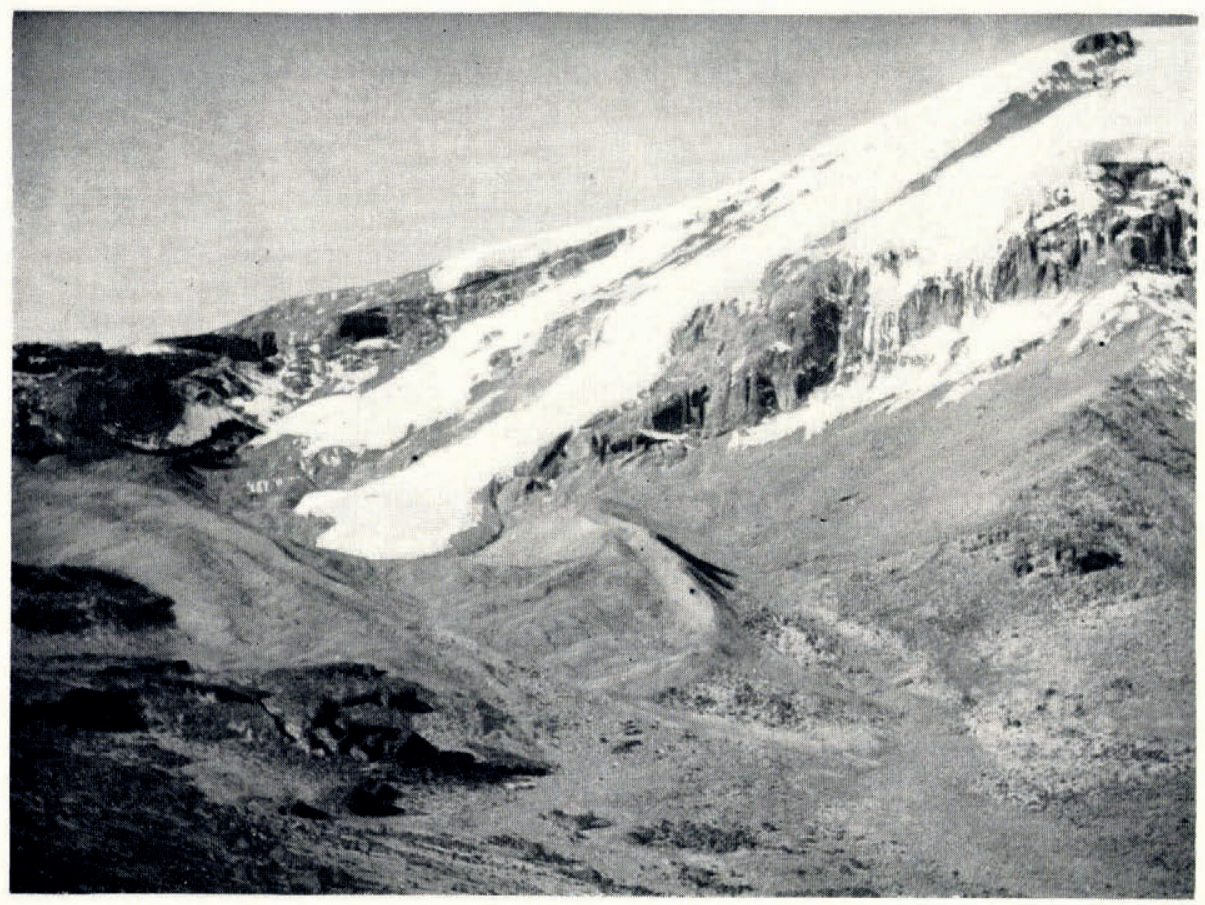

Fig. 2. The Penck Glacier, Kibo, Kilimanjaro, showing the "tooth-paste" form of the glacier and the lateral and terminal moraines 